\title{
Morphological Characterization of Different Rice Genotypes under Drought Stress Conditions
}

\author{
Ritika Yadav* and Gurdeep Bains \\ Govind Ballabh Pant University of Agriculture and Technology, Pantnager, Udham Singh \\ Nagar District (Uttrakhand), India \\ *Corresponding author
}

\section{A B S T R A C T}

\begin{tabular}{l}
\hline K e y w o r d s \\
$\begin{array}{l}\text { Drought, Rice, } \\
\text { Plant height, Total } \\
\text { dry matter, Leaf } \\
\text { area index, Grain } \\
\text { yield, } 1000 \text { grain } \\
\text { weight }\end{array}$ \\
\hline $\begin{array}{l}\text { Article Info } \\
\text { Accepted: } \\
\text { 17 January } 2021 \\
\text { Available Online: } \\
\text { 10 February } 2021\end{array}$ \\
\hline
\end{tabular}

\section{Introduction}

Rice is mostly cultivated for direct food consumption by 3 billion people in the world. After wheat, rice is the second largest consumed crop which provides $80 \%$ calorie for world's population whereas, the consumption of rice in the world increased by $40 \%$ in last 30 years (Anonymous, 2015).It is a semi-aquatic plant and production of rice is very sensitive to drought stress (Wassmann et al., 2009). Drought is the most common and complex phenomenon which can occur at any time for a long period, affecting a large array of physiological, biochemical and molecular process (Geng et al., 2008). Drought stress is 
the insufficiency of moisture content in the soil resulting in the reduction of growth, development and yield of rice plant (Blum, 2011).To cope up with drought stress, different morphological, biochemical and physiological adaptations are there (Tripathy et al., 2000). Morphological characteristics like root/shoot length, leaf area, leaf length and width are affected by drought stress. To survive under stress there is increase in root length and decrease in leaf area. Rice plant can avoid drought stress through increased root length which helps plant to extract water from deeper soil layer and decreased transpiration rate by leaf rolling (Gouda et al., 2012). Secondly, rice can escape from drought through short growth duration of genotype to avoid terminal drought stress (Bing et al., 2006). Different physiological mechanisms such as osmotic adjustment (Wei et al., 2014), stomatal conductance (Comstock 2002) or drought response index (DRI) are the important traits used by rice plant to avoid stress (Guan et al., 2010). Rice plants affected by drought stress show increase in chlorophyll content, proline content, and total soluble content but show decrease in amylose and malondialdehyde content (Wei et al., 2014). Rice can recover from drought which occur during vegetative growth but it cannot recovered during flowering stage result in reduction in grain yield (Xangsayasane et al., 2014).Drought stress shows its effects at cellular level by hindering the cell division or in cell elongation, thus decreases in turgor pressure (Skoto and Muhammad, 2014). Cell elongation is more effected by drought stress causing shunted growth (Jaleel et al., 2009). Thus, drought stress shows retarded development in root and reduction in photosynthetic rate by closing stomata that limits diffusion of $\mathrm{CO}_{2}$. Due to drought conditions, there is variation in photosynthetic pigment such as chlorophyll and carotenoids which directly affect photosynthetic rate and ultimately affect economic yield (Yang et al., 2014).
Drought is an environmental disaster that reduces production of rice. For crop production drought is the most limiting factor which directly affects productivity of rice and it is a very severe problem in many regions of the world (Mostajeran and Eichi, 2009).Creating drought tolerant varieties of rice is an important challenging task for agriculturist. To facilitate the development of tolerant varieties which survive and give better yields under drought conditions, a thorough understanding of the various morphological, biochemical, physiological and molecular characters that govern the yield of rice under water stress condition is a prerequisite. Eastern India is highly vulnerable to abiotic stresses such as drought, salinity, alkalinity, periodic cycles of submergence, low soil fertility, flooding and mineral nutrient deficiency. Therefore, productivity of rice in this particular area is low. A large portion of the world's farms are rain fed where the water supply is unpredictable and droughts are common. By using high yielding varieties in china and increasing chemical fertilizers the increase in yield of rice was found from 1970 to 1990 is $3.37 \%$ (Anonymous, 2005). Because of green revolution, food security in Asia has improved in past decades due to which there is increase in productivity of rice. The total rice growing area is 151 million ha of world land out of which one third area is under rainfed lowlands (Anonymous, 2005), where, rice is grown bunded fields under nonirrigated conditions, only depends on natural rain. During the growing season the only cause of crop failure in rainfed lowland rice cultivation is insufficient rainfall. Because of continuous increase in global population, the demand of rice production is also increasing. It is predicted that the world's population will increase by 8 billion till 2030, therefore there is need to increase rice productivity by $40 \%$ (Bernier et al., 2008). The enhancement of rice yields in drought stress has been a goal of 
agricultural scientist for several decades. In present study, 16 genotypes of rice are evaluated under drought stress condition.

\section{Materials and Methods}

The present investigation was carried out during kharif 2015 at Dr N.E. Borlaug's Crop Research Centre and Department of Plant Physiology, College of Basic Sciences and Humanities, Govind Ballabh Pant University of Agriculture and Technology, Pantnager, Udham Singh Nagar District (Uttrakhand). The seeds of rice genotypes, namely, IET 22747, IET 23216, IET 23223, IET 23335, IET 23337, IET 24672, IET 24674, IET 24677, IET 24683, PHY 1, PHY 2, PHY 4, PHY 5, PHY 6, PHY 7, PHY 8, were obtained from the Directorate of Rice Research, Rajendranagar, Hyderabad. The seeds of all genotypes were sown on 15 June 2015 and the seedlings were transplanted on $6^{\text {th }}$ July 2015. The drought stress treatment was given during flowering by stopping the supply of water. The control block/strip was supplied with water at regular time interval. Different morphological e.g. Plant height, Number of tillers, total dry matter, grain yield, Leaf area index and 1000 grain weight were studies during this experiment.

\section{Results and Discussion}

\section{Plant height}

The data presented in fig. 1 shows that compared to control, the plant height decreases in all the rice genotypes under drought stress. At flowering, the maximum plant height was found in PHY $8(130.44 \mathrm{~cm})$ and minimum in IET $23216(105.89 \mathrm{~cm})$ under control condition but during drought stress the maximum plant height was found in PHY 2 $(116.0 \mathrm{~cm})$ and minimum was found in IET $24677(95.36 \mathrm{~cm})$. The percentage reduction in plant height due to drought stress in decreasing order as follows: PHY 4 (22.75) > IET 24677 (20.83) > PHY 8 (20.78) > PHY 5 (19.25) > IET 23223 (18.48) > PHY 7 (16.90) $>$ IET 23335 (16.89) > IET 23337 (12.65) > PHY 6 (12.36) > IET $24672(12.07)>$ IET 24683 (10.01) > IET 24674 (8.89) > PHY 1 (7.96) > PHY 2 (6.45) > IET 22747 (5.89) > IET 23216 (5.35). The maximum percent reduction (\%) was observed in PHY 4 (22.75) and minimum in IET 23216 (5.35).

\section{Number of tillers}

Tillers are branches that develop from the leaf axils at each unelongated node of the main shoot or from other tillers during vegetative growth. When the fifth leaf on the main culm emerges, the first leaf of the tiller comes from the axil of the second leaf on that culm. Similarly, when the sixth leaf on the main culm emerges, the first leaf of the tiller comes from the axil of the third leaf on that culm. The data presented in fig. 2 shows that under drought stress condition the number of tillers per plant at flowering increased in 11 rice genotypes- IET 22747, IET 23335, IET 23337, IET 24674, IET 24677, IET 24683, PHY 2, PHY 4, PHY 5, PHY 6 and PHY 7, while it decreased in rest of the genotypes namely PHY 8, PHY 1, IET 24672, IET 23223, IET 23216. At flowering, the maximum number of tiller was found in IET 24672 (8.56) and minimum in IET 23335 (4.56) under control condition but during drought stress the maximum number of tiller was found in IET 24672 (7.89) and minimum was found in PHY 8 (6.01). The percentage reduction in number of tiller due to drought stress of different rice genotypes in decreasing order were as follows- PHY 8 (19.11) > PHY 1 (17.91) > IET 23216 (13.23) $>$ IET 24672 (7.79) > IET 23223 (3.50). The maximum percent reduction $(\%)$ was observed in PHY 8 (19.11) and minimum in IET 23223 (3.50). The percentage increase in number of tiller of different rice genotypes in 
decreasing order were as follows- IET 23335 (68.29) > PHY 4 (36.73) > IET 24683 (34.78) $>$ PHY 7 (25.00) > IET 22747 (16.32) > PHY $2(12.00)>$ IET $24677(8.35)>$ IET 23337 (7.40) > PHY 6 (7.14) > PHY 5 (6.15) > IET 24674 (3.12). The maximum percent increase (\%) was observed in IET 23335 (68.29) and minimum in IET 24674 (3.12)

\section{Total dry matter}

The data presented in fig. 3 shows that under drought stress, the total dry matter at flowering decreases in all rice genotypes. The maximum total dry matter was found in IET $24672\left(2062.58 \mathrm{~g} / \mathrm{m}^{2}\right)$ and minimum was in IET $23335\left(1208.33 \mathrm{~g} / \mathrm{m}^{2}\right)$ in control The maximum total dry matter was observed in rice genotype IET $23337\left(1790.83 \mathrm{~g} / \mathrm{m}^{2}\right)$ and minimum was in IET $24674\left(728.39 \mathrm{~g} / \mathrm{m}^{2}\right)$ under drought stress. It was non-significant for treatment (T), but significant for genotypes $(\mathrm{G})$ and $\mathrm{T} \times \mathrm{G}$ interactions. The percentage reduction in total dry matter in decreasing order were as follows - IET 24674 (60.62) > IET 23223 (56.14) > PHY 5 (54.67) $>$ IET 22747 (50.77) > PHY 2 (49.03) > IET 23216 (43.55) > PHY 4 (43.23)> PHY 8 $(41.44)>$ IET $24677(40.95)>$ IET 24683 (31.54) > PHY 7 (31.24) > PHY 6 (23.36) > IET $24672(20.70)>$ IET 23335 (15.67) > IET 23337 (7.77). The maximum percent reduction was observed in IET 24674 (60.62) and minimum in IET 23337 (7.77).

\section{Grain yield}

The data presented in fig. 4 shows that the grain yield per $\mathrm{m}^{2}\left(\mathrm{~g} / \mathrm{m}^{2}\right)$ at harvest decreases in all the rice genotypes under drought stress treatment as compared to control. The maximum grain yield was observed in PHY 4 (1013.33) and minimum in PHY 8 (717.00) under control condition. It was maximum in rice genotype IET 23216 (770.00) and the minimum was in IET 24672 (363.00) under drought stress treatment. It was statistically non-significant for treatment $(\mathrm{T})$, but significant for genotypes (G) and $T \times G$ interactions.

The percentage decrease in grain yield (Economic yield) of different genotypes in decreasing order were as follows- IET 24672 (52.47) > PHY 4 (49.24) >PHY 8 (37.24) > IET 24674 (36.60) > IET 24683 (33.58) > IET 23335 (31.19) > PHY 7 (27.96) > IET 24677 (26.34) > IET 23223 (24.17) > IET 23337 (23.98) > PHY 6 (23.32) > IET 23216 (17.09) > PHY 1 (14.85) > IET 22747 (14.67) $>$ PHY 2 (13.37) > PHY 5 (12.80). The maximum percent reduction (\%) was observed in IET 24672 (52.47) and minimum in PHY 5 (12.80).

\section{Leaf area index}

The data presented in fig. 5 shows that under drought stress treatment the leaf area index decreased in all the rice genotypes. It was maximum in IET 24683 (6.49) and minimum in IET 24672 (5.09) under control condition.

The maximum leaf area index was recorded in rice genotype PHY 1 (4.80) and the minimum was recorded in IET 24677 (2.65) under drought treatment. It was statistically nonsignificant for treatment $(\mathrm{T})$, but significant for genotypes $(\mathrm{G})$ and $\mathrm{T} \times \mathrm{G}$ interactions. The percentage reduction in leaf area index (LAI) in different rice genotypes under drought stress in decreasing order were as followsIET 23335 (56.02) > IET 24677 (51.99) > PHY 5 (47.56) > IET 22747 (47.32) > IET 23223 (43.89) > PHY 6 (43.31) > IET 24683 (43.25) > PHY 4 (40.86) > IET 24674 (38.75) $>$ PHY 7 (37.28) > IET 23337 (35.94) > PHY 8 (34.24) > PHY 2 (29.65) > PHY 1 (22.64) > IET 24672 (21.77) > IET 23216 (17.89). The maximum percent reduction was observed in IET 23335 (56.02) and minimum in IET $23216(17.89)$. 
Fig.1 Plant height at flowering of different genotypes of rice under control and drought stress condition

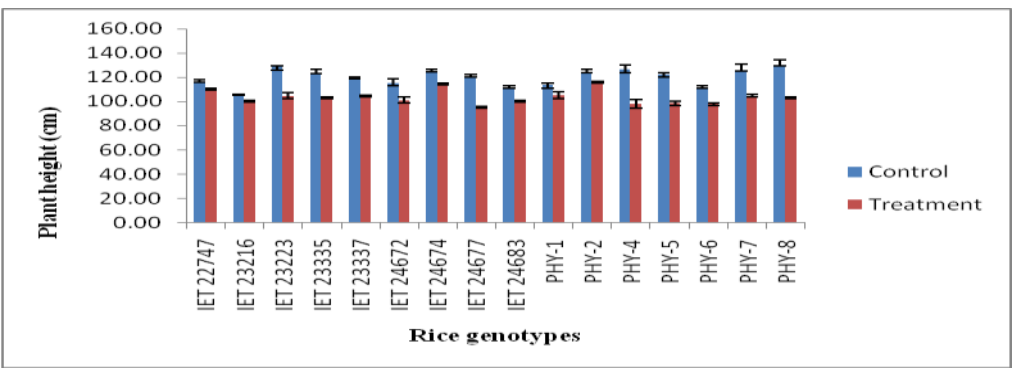

Fig.2 Number of tillers at flowering of different genotypes of rice under control and drought stress treatment

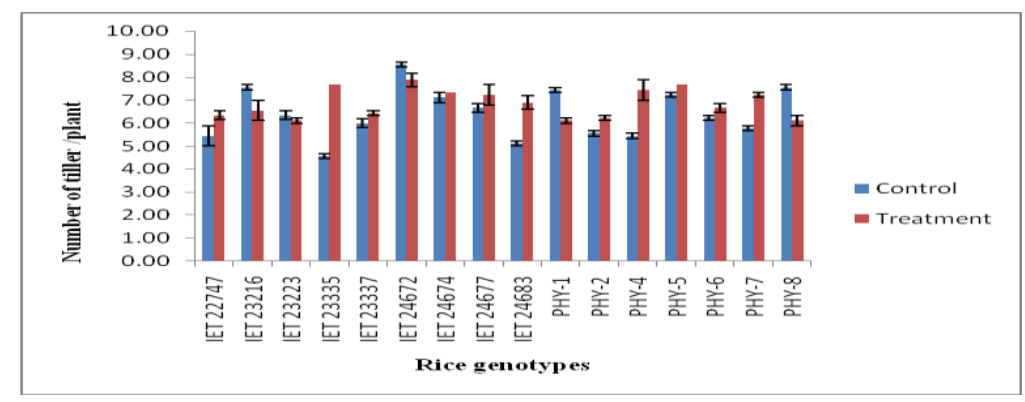

Fig.3 Total dry matter at flowering of different genotypes of rice under control and drought stress

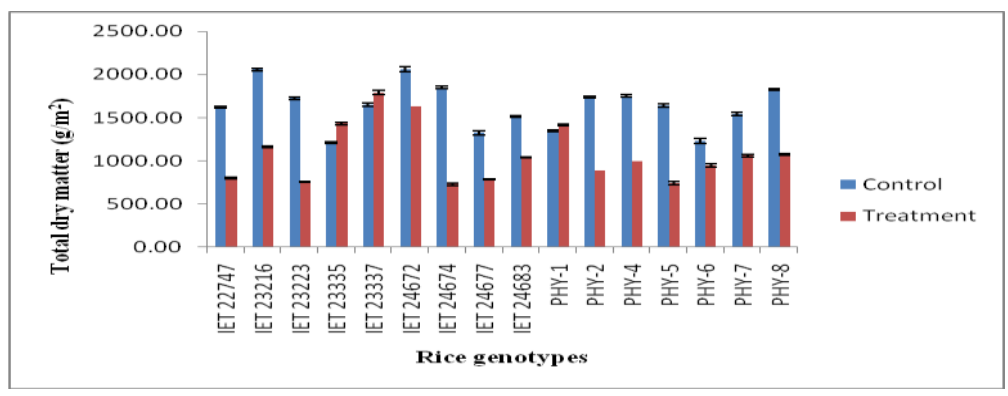

Fig.4 Grain yield of different genotypes of rice under control and drought stress treatment

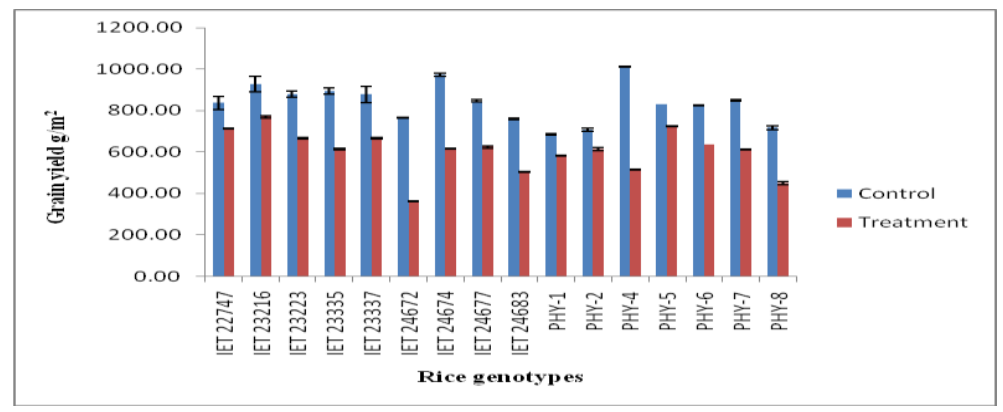


Fig.5 LAI of different genotypes of rice under control and drought stress treatment

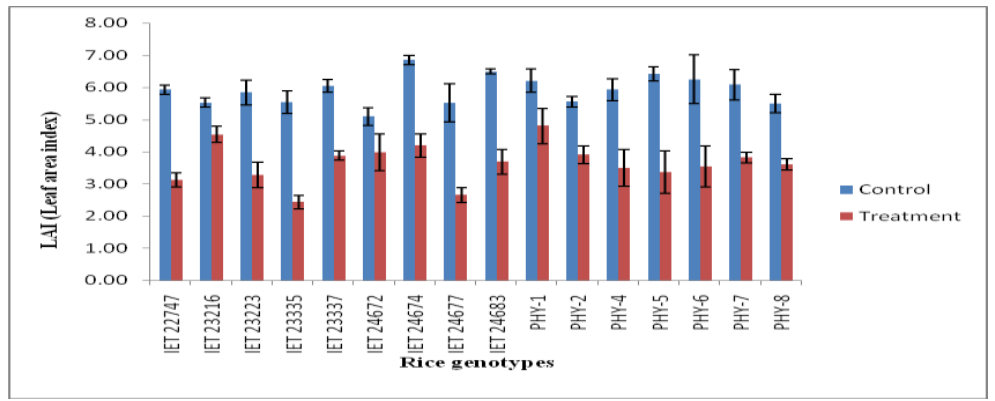

Fig.6 1000 grain weight of different genotypes of rice under control and drought stress treatment
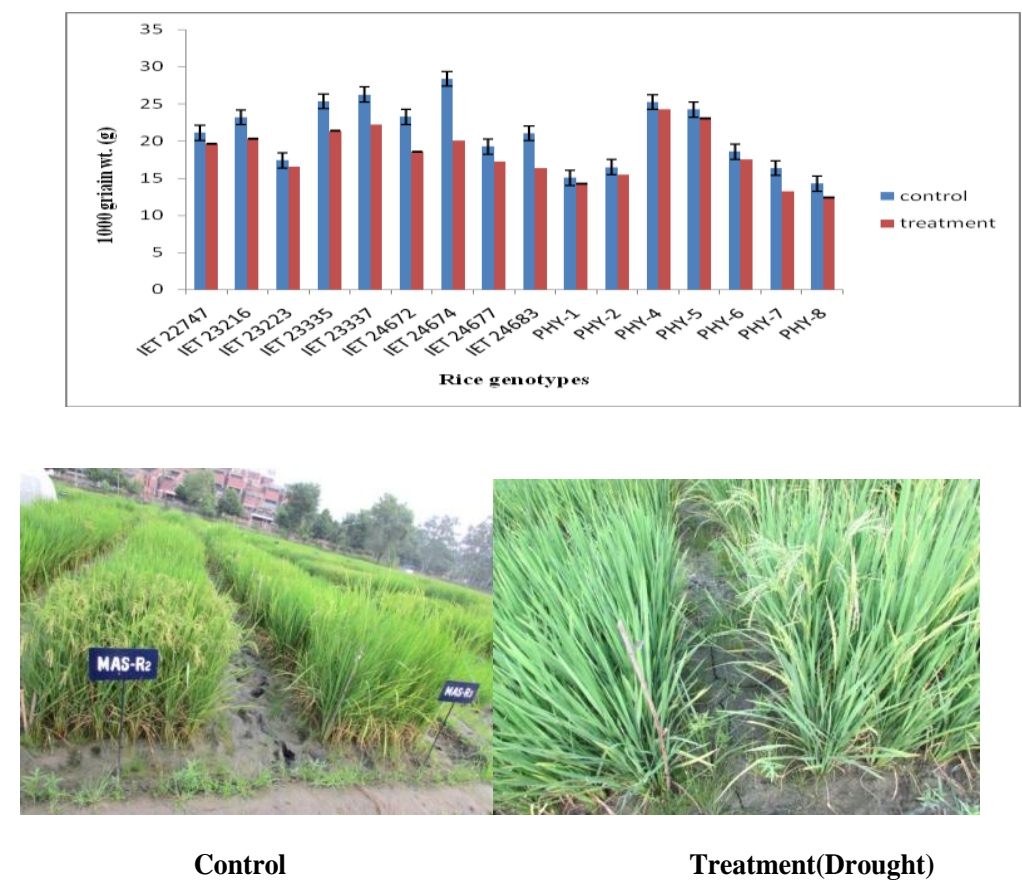

\section{0 grain weight}

Data presented in Fig. 6 under drought stress treatment depicts that 1000 grain weight was decreased in all the rice genotypes. It was maximum in IET $24674(28.35 \mathrm{~g})$ and minimum in PHY 8 (14.25) under control condition. The maximum 1000 grain weight was observed in rice genotype PHY 4 $(24.23 \mathrm{~g})$ and the minimum was recorded in PHY8 (12.38g) under drought treatment. It was statistically non-significant for treatment $(\mathrm{T})$, but significant for genotypes $(\mathrm{G})$ and
$\mathrm{T} \times \mathrm{G}$ interactions. The percentage reduction in thousand grain weight due to drought stress of different genotypes of rice in decreasing order were as follows- IET 24674 (29.28) > IET 24683 (22.25) > IET 24672 (20.26) > PHY 7 $(18.87)>$ IET 23335 (15.85) > IET 23337 (15.31) > PHY 8 (13.12) > IET 23216 (12.34) $>$ IET $24677(10.35)>$ IET 22747 (6.83) > PHY 2 (6.13) > PHY 6 (5.60) > PHY 1 (5.13) $>$ PHY 5 (4.83) > IET 23223 (4.78) > PHY 4 (4.04). The maximum percent reduction was observed in IET 24674 (29.28) and minimum in PHY 4 (4.04). 
The plant height is the most important agronomic trait of rice which is controlled by environmental conditions. Plant height is attributed to rate of culm elongation, number of internode per plant, elongation in leaf and leaf blade. The culm is composed of series of nodes and internodes. Internode elongation is closely associated with growth duration. Due to decrease in turgor pressure, cells growth is sensitive to drought stress. During division in meristematic cells, the production of daughter cells, leads to increase in cell growth. Less absorption of water by xylem during stress condition inhibit the division in meristamatic cells due to which there is less production of daughter cells and ultimately reduction in cell growth (Nonami, 1998). The results suggest that as drought stress increases there is decrease in plant height. They are inversely related to each other. It might be due to the reduction in cell division or reduction in cell enlargement under drought stress (Islam et al., 2001).

Drought affects expansion of growth as well as elongation of growth (Shao et al., 2008) which reduces cell enlargement more as than cell division (Jiang et al., 2007) and also impair number of tillers (Mostajeran et al., 2009). The number of productive tillers, grain weight and spikelet sterility are the most important components of yield (Sheehy et al., 2001) that are affected by different environmental factors like abiotic and biotic stress among which drought is considered to be agronomically important. Drought stress during vegetative stage reduces number of tillers. Water stress during tillering or before also reduces tiller number. Production of tillers is highly sensitive to drought stress and tiller production in rice is an agronomical important trait (Li et al., 2003). Tiller number is also correlated with dry weight of panicle (Paulsen, 1987). The results show that the number of tillers per hill decreased under drought stress. The reduction in no of tillers during drought stress might be due to the insufficient production of assimilates or may be the plant cannot carry out normal physiological activities such as photosynthesis etc. under water stressed condition (Zubarer et al., 2007). Total number of tillers per plant might be increased as a result of short term high temperature during vegetative growth. The number of tillers per square meter during the early growth period was generally larger under temperature and the maximum tillering stage was earlier than under normal temperature conditions (Yang and Heilman, 1993).

Results also suggested that there is decrease in total dry matter in rice genotypes. It might be due to inhibition of photosynthetic rate. The results are in confirmation with previous workers (Hossain, 2001). The dry matter allocation in leaf blade, leaf sheath, culm and panicle were influenced greatly by drought stress. The increase in total dry matter might be due to weight increase in culm plus leaf sheath i.e. the partitioning increases in straw carbon. At flowering, dry weight of panicle decreased and was supposed to be induced by pollen sterility, which lead to the nutrient transport impeded at culm and resulted in the dry matter increase in culm plus leaf sheath (Guo-hua et al., 2013).

At booting stage (Pantuwan et al., 2002), drought stress can interrupt with floret initiation which causes sterility in spikelet and due to this there is decrease in grain yield and ultimately poor paddy yield (Kamoshita et al., 2004). Water-stress decreases productivity via reducing the filling period of grain, through disturbing gas exchange characteristics of leaf, disrupting transport and loading through phloem and reducing the length of tissues of source and sink (Farooq et al., 2009). Reduction in productivity might be due to decrease in rate ofCO $\mathrm{O}_{2}$ assimilation, decrease in conductance via stomata, photosynthetic 
pigments, short size of leaf, decreased extension of stem, reduced water status, decreased WUE, decreased in activities of enzymes which synthesize sucrose and starch, such that this leads to a decrease in yield and development of (Anjum et al., 2011). Reduction in economic yield in rice genotypes might be due to the inhibition of rate of photosynthesis and reduced translocation of assimilates towards reproductive parts due to less soil moisture. The result are in confirmation with Hossain (2001) who conducted pot experiment under different level of drought and observed that grain yield decreased with decrease in soil water level.

Due to drought stress there is decrease in plant leaf and width and finally decrease in leaf area. Decrease in leaf area index under drought stress might be due to reduction in cell division of meristematic tissue. The results of the experiment are in agreement with earlier work (Hossain, 2001)

It was found that severe drought stress decreases $90 \%$ yield by affecting spikelet sterility, grain width, grain length and finally decrease in grain weight (Mohammed et al., 2010). The decline in weight of grains might also be due to the drought induced reduction in leaf size, disturbed plant water relations, reduced assimilate partitioning, and finally reduction in weight of grain. (Anjum et al., 2001). The reduction in grain weight depends on the duration of drought stress, drought severity and stage of crop growth (Kumar et al., 2014). Similar results were recorded by (Islam et al., 1994).

\section{Acknowledgment}

The authors are highly grateful to all india Coordinated Rice improvement Project (AICRIP) ICAR., IIRR Hyderabad and Department of Plant Physiology, G.B.P.U.A.
\& T., Pantnagar for providing the necessary facilities during the cource of investigation.

\section{References}

Anjum, S. A., Xie, X., Wang, L., Saleem, M. F., Man, C., and Lei, W. 2011. Morphological, physiological and biochemical responses of plants to drought stress. Afr. J. Agric. Res. 6(9): 2026-2032.

Anonymous, 2005. Rice is life: scientific perspective for the $21^{\text {th }}$ century.

Anonymous, 2015. FAOSTAT Database.

Bernier, J., Atlin, G., Serraj, R., Kumar, A., and Spaner, D. 2008. Review: breeding upland rice for drought resistance. $J$. Sci. Food Agric. 88: 927-939.

Bing, Y., Weiya, X., Lizhong, X., Xinqiao, Y., Lijun, L., Kehui, C., Deming, J., Yongzhong, X., and Qifa Z. 2006. Genetic basis of drought resistance at reproductive stage in rice: Separation of drought tolerance from drought avoidance. Genetics. 172: 1213-1228.

Blum, A. 2011. Drought resistance - is it really a complex trait? Func. Plant Biol. 38:753-757.

Comstock, J.P., 2002. Hydraulic and chemical signaling in the control of stomatal conductance and transpiration.J. Exp. Bot. 53: 195-200.

Farooq, M., Wahid, A., and Lee, D. J. 2009b. Exogenously applied polyamines increase drought tolerance of rice by improving leaf water status, photosynthesis and membrane properties. ActaPhysiol. Plant.31(5): 937-945.

Geng, P., and Cooper, M. 2008 Effect of drought on reagenration of embryonic calli in upland rice varieties. Plant Cell Tissue Organ Cult. 92:303-313.

Gouda, P.K., Varma, C.M.K., Saikumar, S., Kiran, B., Shenoy, V., and Sashidhar, H.E. 2012.Direct selection for grain 
yield under moisture stress in Oryzasativa cv. IR58025B x $O$. meridionalis population. Crop Sci. 52: 644-653.

Guan, YS., Serraj, R., Liu, SH., Xu, JL., Ali, J., Wang, W., Venus, E., Zhu, LH., and Li, ZK. 2010. Simultaneously improving yield under drought stress and non-stress conditions: A case study of rice (Oryza sativa L.). J Exp Bot 61: 4145-4156.

Guo, Y., Cai, W., Tu, K., Tu, S., Wang, S., Zhu, X., and Zhang, W. 2013. Infrared and Raman spectroscopic characterization of structural changes in albumin, globulin, glutelin, and prolamin during rice aging. J. Agric. Food Chem. 61:185-192.

Hossain, M.A., 2001. Growth and yield performance of some boro rice cultivars under different soil moisture regimes M.S. Thesis, Dep. Crop Bot. Bangladesh Agric. University; Mymensinghin rice. Nature.422: 618621.

Hossain, M., A. 2001. Growth and yield performance of some boro rice cultivars under different soil moisture regimes M.S. Thesis, Dep. Crop Bot. Bangladesh Agric. University; Mymensinghin rice. Nature.422: 618621.

Islam, M.T., and Gretzmacher, R. 2001. Grain growth pattern and yield performance of some transplanted aman rice cultivars in relation to moisture stress. B.J. Nuclear. Agric. 16-17:21-28.

Islam, M.T., Salam, M.A., and Kauser, M. 1994. Effect of soil water stress at different growth stages of rice on yield components and yield. Progress Agric. 5(20): 151-156.

Jaleel, C. A., Manivannan, P., Wahid, A., Farooq, M., Al-Juburi, H. J., Somasundaram, R., and Panneerselvam, R. 2009. Drought stress in plants: A review on morphological characteristics and pigments composition. Int. J. Agric. Biol.11: 100-105.

Jiang, S.L., Wu, J.G., Feng, Y., Yang, X.E., and Shi, C.H. 2007. Correlation analysis of mineral element contents and quality traits in milled rice (Oryza stavia L.). J. Agric. Food Chem. 55:9608-9613.

Kamoshita, A., Rofriguez, R., Yamauchi, A., and Wade, L. J. 2004.Genotypic variation in response of rainfed lowland to prolonged drought and re-watering. Plant Prod. Sci. 7(4): 406-420.

Kumar, A., Dixit, S., Ram, T., Yadaw, R. B., Mishra, K. K., and Mandal, N. P. 2014. Breeding high-yielding drought-tolerant rice: Genetic variations and conventional and molecular approaches. J. Exp. Bot. 65(21): 6265-6278.

Li, X., Qian, Q., Fu, Z., Wang, Y., Xiong, G., Zeng, D., Wang, X., Liu, X., Teng, S., Hiroshi, F., Yuan, M., Luok, D., Han, B., and Li, J. 2003.Control of tillering in rice. Letters to Nature.422: 618-621.

Mohammed, A.R., and Tarpley, L. 2009. High nighttime temperatures affect rice productivity through altered pollen germination and spikelet fertility. Agric. Forest Meteorol. 149: 999-1008.

Mostajeran, A., and Rahimi-Eichi, V. 2009. Effects of drought stress on growth and yield of rice (OryzasativaL.) cultivars and accumulation of proline and soluble sugars in sheath and blades of their different ages leaves. Am. Eur. J. Agric. Environ. Sci. 5(2): 264-272.

Mostajeran, A., and Rahimi-Eichi, V. 2009. Effects of drought stress on growth and yield of rice (Oryza sativa L.) cultivars and accumulation of proline and soluble sugars in sheath and blades of their different ages leaves. Am. Eur. J. Agric. Environ. Sci. 5(2): 264-272.

Nonami, H., 1998. Plant water relations and control of cell elongation at low water potentials. J. Plant Res. 111: 373-382. 
Pantuwan, G., Fukai, S., Cooper, M., Rajatasereekul, S., and O'Toole, J. C. 2002. Yield responses of rice (Oryza sativa L.) genotypes to drought under rainfed lowlands: 2. Selection of drought resistant genotypes. Field Crops Res. 73(2/3): 169-180.

Paulsen, G.M., 1987. Wheat stand establishment. In: Heyne, E.G. (Ed.), Wheat and wheat improvement. American Society of Agronomy Monograph, Madison, WI, USA, pp. 384-391.

Shao, H. B., Chu, L. Y., Shao, M. A., Jaleel, C. A., and Mi, H. M. 2008. Higher plant antioxidants and redox signaling under environmental stresses. Comp. Rend. Biol.331: 433-441.

Sheehy, J.E., Mitchell, P.L., and Ferrer, A. B. 2001. Decline in rice grain yields with temperature: Models and correlations can give different estimates. Field Crops.Res. 98: 151-56.

Sokoto, M. B., and Muhammad, A. 2014. Response of rice varieties to water stress in Sokoto, Sudan Savannah, Nigeria. J. Biosci. Med. 2(1): 68-74.

Tripathy, J.N., Zhang, J., Robin, S., and Nguyen, H.T. 2000. QTLs for cellmembrane stability mapped in rice (Oryza sativa L.) under drought stress. Theor. Appl. Genet. 100: 1197-1202.

Wassmann, R., Jagadish, S.V.K.S., Heuer, S., Ismail, A., Redona, E., Serraj, R., Singh, R.K., Howell, G., Pathak, H., and Sumfleth, K. 2009. Climate change affecting rice production: the physiological and agronomic basis for possible adaptation strategies. $A d v$. Agron. 101:59-121.

Wei, S., Hu, W., Deng, X., Zhang, Y., Liu, X., Zhao, X., Luo, Q., Jin, Z., Li, Y., Zhou, S., Sun, T., Wang, L., Yang, G., and He, G. 2014. A rice calciumdependent protein kinase OsCPK9 positively regulates drought stress tolerance and spikelet fertility. $B M C$ Plant Biology, 14: 133.

Xangsayasane, P., Jongdee, B., Pantuwan, G., Fukai, S., and Mitchell, J.H. 2014.Genotypic performance under intermittent and terminal drought screening in rainfed lowland rice. Field Crops Res. 156: 281-292.

Yang, C.M., and Heilman, J. L. 1993. Responses of rice (Oryza sativa L.) to short term high temperature: growth, development and yield. J. Agric. Res. China. 42(1) 1-11.

Yang, P. M., Huang, Q. C., Qin, G. Y., Zhao, S. P., and Zhou, J. G. 2014. Different drought- stress responses in photosynthesis and reactive oxygen metabolism between autotetraploid and diploid rice. Photosynthetica, 52(2): 193-202.

Zubarer, M.A., Chowdhury, A.K.M.M.B., Islam, M.Z., Ahmed T., and Hasan, M.A. 2007. Effects of water on growth and yield attributes of rice genotypes. Int. J. of Sustainable Crop Prod. 2(6): 25-30.

\section{How to cite this article:}

Ritika Yadav and Gurdeep Bains. 2021. Morphological Characterization of Different Rice Genotypes under Drought Stress Conditions. Int.J.Curr.Microbiol.App.Sci. 10(02): 2243-2252. doi: https://doi.org/10.20546/ijcmas.2021.1002.267 